\title{
Study of Differences in Purchase Behaviour for High Involvement Consumer Durable Goods in Districts of Rajasthan
}

\author{
U.C. Sharmaa ${ }^{a}$ Mayank Sharma ${ }^{b^{*}}$ \\ a,bDepartment of Commerce E Business Administration, M.M.H College, Ghaziabad (U.P.) India \\ Affiliated to Chaudhary Charan Singh University, Meerut (U.P.) India \\ Email Id:mayankmax216@gmail.com
}

\begin{abstract}
In a globalised economy, markets are characterized by competition. The fast innovations of technologies are intensifying the intensity of competition and are becoming challenge for every business. In the past few years, due to competition, continuously company margins are considerably declining. According to Philip Kotler (2003), in hyper competition, power is clearly shifting to consumers who are increasingly telling what product features they want, what communication they will tolerate, what incentives they expect and what price they will pay. It is high time for marketers to study, understand and predict consumer behaviour in order to survive, sustain and grow in this highly competitive and volatile market. In fact, consumer behaviour is the process whereby individuals decide whether, what, when, where, how and from whom to purchase goods and services (Walter and Paul, 1970). As a field of study, consumer behaviour focuses upon consumer activities (Blackwell, Miniard, Engel, 2001). Moreover, the scholars of human behaviour are highly concerned to study the consumer behaviour in order to gain deeper insights into why individuals are involved in certain consumption related behaviour and interested to know what internal and external factors influences them in their consumption related decisions. Zikmund (2001) is of opinion that human behavior of any kind $(B)$ is a function $(f)$ of the interaction between the person $(P)$ and the environment $(E)$-that is $B=f(P, E)$.

According to Zikmund, consumer behaviour is the function of personal factors (age and stages of life cycle, occupation, economic situation, life style, personality, psychology etc.) and environmental factors (culture, sub-culture, social class, reference groups, family, role and status).
\end{abstract}

Keywords: Consumer buying behaviour, High involvement products, Socioeconomic status.

\section{PAPER/ARTICLE INFO} RECEIVED ON: 26/07/2019 ACCEPTED ON: 19/12/2019

Reference to this paper should be made as follows:

U.C. Sharma, Mayank Sharma (2019), "Study of Differences in Purchase Behaviour for High Involvement Consumer Durable Goods in Districts of Rajasthan", Int. J. of Trade and Commerce-IIARTC, Vol. 8, No. 2, pp. 348-356 


\section{INTRODUCTION}

Social class as a factor influencing consumer buying behavior has been studied by many researchers both in India and abroad. In an earlier study Warner and Paul (1941) have identified that different social classes display different purchase goals and shopping behaviours. Warner (1949) found from his study that buying habits of lower class persons are profoundly different from middle class persons. What each person buys and where he purchases, is symbolic as well as has economic values. Martineau (1958) found from his study that the individual's consumption pattern actually symbolises his class position. Social class is often more significant determinant of his buying behaviour than income. Kahl (1957) found from his study that kinds of things a person will buy or will not buy are strongly related to his class membership.

Vidich and Bensman (1960) found that lower class people prefer to spend their money on immediate needs and fancies. Brown, Gray and Korgaonkar (1992) found role of consumer's social class while making purchases via electronic shopping.

It is found that consumers from the higher social classes show progressively less interest in electronic shopping as their income and status increase in comparison to lower social class consumers. Thus, though there exist many more studies both in India and abroad with respect to the impact of internal and external factors separately or together influencing consumers buying behavior but a study on how social classes as an external determinant determines consumer buying behavior especially for High Involvement Products (HIPS), in the state of Rajasthan is conspicuously scanty. Hence the present study is a modest attempt to investigate the impact of social factors on consumer buying behavior.

\section{OBJECTIVES OF THE STUDY}

Following were the objectives of the study:

1. To investigate the impact of social class as one of the factor influencing consumer buying behaviour in selected High Involvement Products (HIPS) in large industrial cities of Rajasthan; and

2. To examine whether consumer buying behavior for selected High Involvement Products (HIPS) differs across different social classes.

\section{Methodology}

The study is based on primary data. Data was collected from the two industrial cities in Rajasthan. The sampling for the study was done at two stages. In the first stage, two major industrial cities viz., Bharatpur and Alwar were purposively selected and in the second stage, 150 respondents from each industrial city (which together constitute 300) were randomly selected on the basis of their car ownership. All respondents were categorized into different social classes on the basis of a standardized social class scale. For this purpose, Kuppuswamy's (1959) "SocioEconomic Status Scale" (urban) was used for measurement of different social class. In fact Kuppuswamy developed and standardized the scale, using three variables namely education, occupation and monthly income. In present study, education, occupations were considered as it is but the third variable income was considered with little modification. In fact monthly income was replaced with annual family income. Then these three variables (education, occupation and 
Study of Differences in Purchase Behaviour for High Involvement Consumer Durable Goods in Districts of Rajasthan U.C. Sharma, Mayank Sharma

annual family income) were combined with the variables of possessions from scale developed by Jalota and others. The modifications were done due to a substantial changes have taken place in the income and possession of people in the society in the last six decades. The changes were made in the possessions so as to include most common items of the present time. The total score of each respondent in the sample was calculated on the basis of weightages assigned to education, occupation, annual family income, and possessions. In case of possessions, if an individual possessed two items, the weightage for that was doubled. Accordingly the entire respondents were categorized into three social classes such as upper class, middle class and lower class. The data collected through questionnaire was analysed with the help of percentages. There are several consumer durable products. For the purpose of this study car, computer, refrigerator and washing machines were chosen with a view to the fact that these products have become a necessicity today.

\section{FINDINGS OF THE STUDY}

Following were the major findings of the study:

I. Source of Information: It is shown in the Table 1 that for buying cars first source of information for majority of respondents in Alwar was "dealer display at showroom" $(24 \%)$, it was "television" (26.6\%) in Bharatpur city. While the most important source of information for majority of respondents for buying computer in Alwar was "magazine" (31.3\%); in Bharatpur it was "newspaper" (28\%). Interestingly for buying refrigerators, T.V. is the first source of information of majority of respondents in both the cities.

Table 1: Source of Information for Buying HIPS

\begin{tabular}{|l|l|l|}
\hline \multicolumn{1}{|c|}{ Products } & \multicolumn{1}{|c|}{ Alwar } & \multicolumn{1}{c|}{ Bharatpur } \\
\hline Car & Dealer display at showroom (24\%) & Television (26.6\%) \\
Computer & Magazine (31.3\%) & Newspaper (28\%) \\
Refrigerator & Television (23.4\%) & Television (36.7\%) \\
Washing Machine & Television (22\%) & Television (35.4\%) \\
\hline
\end{tabular}

Source: Primary data

Alwar and Bharatpur was "television" (23.4\% and 36.7\%, respectively). Even for buying washing machines as for majority of respondents both in Alwar and Bharatpur was "television" (22\% and $35.4 \%$, respectively) emerged to be the first source of information. The similarity of sources of information for buying the refrigerator and washing machine is television could be due to the fact these products are being used by women for their day to day needs and spouses of majority of the respondents are housewives, therefore, television emerged to be the major source of information for buying these HIPS, which could be used by marketers to advertise their products.

II. Time taken to Think and Buy HIPS: Table 2 shows that majority of the respondents in the study in both city belong to middle social class $68 \%$ in Alwar and $68.75 \%$ in Bharatpur. 
While it was followed by upper social class $20.7 \%$ in Alwar and only $10 \%$ in Bharatpur. In the sample, in Bharatpur 21.3\% belong to lower social class and in Alwar it was $11.3 \%$. While the similarity in middle class respondents in both the city could be attributed to the fact that these respondents could be employed and their income and spending habits are almost similar, but the difference in upper social class in both the city could due to that, Alwar being industrial city some of the respondents being senior executives in Alwar Steel Plant have higher income.

Table 2: Time taken to think and buy HIPS

\begin{tabular}{|c|c|c|c|c|c|c|}
\hline \multirow[t]{2}{*}{ Products } & \multicolumn{3}{|c|}{ Alwar } & \multicolumn{3}{|c|}{ Bharatpur } \\
\hline & Upper Class & Middle Class & Lower Class & Upper Class & Middle Class & Lower Class \\
\hline Car & $\begin{array}{c}\text { Less than } 1 \\
\text { week }(51.6 \%)\end{array}$ & $\begin{array}{c}\text { Immediate } \\
\text { Decision } \\
(45.1 \%)\end{array}$ & $\begin{array}{c}\text { Less than } 1 \\
\text { week }(29.4 \%)\end{array}$ & $\begin{array}{l}15 \text { days } \\
(53.3 \%)\end{array}$ & $\begin{array}{c}1 \text { Month } \\
(36.9 \%)\end{array}$ & $\begin{array}{c}\text { More than } \\
\text { one month } \\
(40.6 \%)\end{array}$ \\
\hline Computer & $\begin{array}{c}\text { Immediate } \\
\text { Decision } \\
(38.7 \%)\end{array}$ & $\begin{array}{c}\text { Immediate } \\
\text { Decision } \\
(49 \%)\end{array}$ & $\begin{array}{l}15 \text { Days } \\
\text { Immediate } \\
\text { Decision } \\
(53.3 \%)\end{array}$ & $\begin{array}{c}\text { Less than } 1 \\
\text { month } \\
(41.2 \%)\end{array}$ & $\begin{array}{l}\text { Less than } 1 \\
\text { week }(32 \%)\end{array}$ & $\begin{array}{c}\text { Less than } 1 \\
\text { week }(28.1 \%)\end{array}$ \\
\hline Refrigerator & $\begin{array}{l}\text { Immediate } \\
\text { Decision } \\
(58.1 \%)\end{array}$ & $\begin{array}{l}\text { Immediate } \\
\text { Decision } \\
(52.9 \%)\end{array}$ & $\begin{array}{l}\text { Immediate } \\
\text { Decision } \\
(35.3 \%)\end{array}$ & $\begin{array}{c}\text { Immediate } \\
\text { Decision } \\
(60 \%)\end{array}$ & $\begin{array}{c}\text { Less than } 1 \\
\text { week }(38.8 \%)\end{array}$ & $\begin{array}{c}\text { Less than } 1 \\
\text { week }(37.5 \%)\end{array}$ \\
\hline $\begin{array}{l}\text { Washing } \\
\text { Machine }\end{array}$ & $\begin{array}{c}\text { Immediate } \\
\text { Decision } \\
(71 \%)\end{array}$ & $\begin{array}{c}\text { Immediate } \\
\text { Decision } \\
(60.8 \%)\end{array}$ & $\begin{array}{c}\text { Immediate } \\
\text { Decision } \\
(47.1 \%)\end{array}$ & $\begin{array}{c}\text { Immediate } \\
\text { Decision } \\
(60 \%)\end{array}$ & $\begin{array}{c}\text { Less than } 1 \\
\text { week }(48.5 \%)\end{array}$ & $\begin{array}{c}\text { Less than } 1 \\
\text { week }(37.5 \%)\end{array}$ \\
\hline
\end{tabular}

Source: Primary data

It is shown in Table 2 that think and buy cars, within upper social class, in Alwar industrial city majority (51.6\%) took "less than a week" time; whereas majority (53.3\%) of their counterparts in Bharatpur took "fifteen days." The difference in think and buy upper class respondents of both the city, which could be due to the fact that Alwar is essentially an industrial town, where majority of the respondents are BSP employees and have loan facility both from bank and their company to buy the cars whereas their counterparts at Bharatpur take little more time because they could be staying with their parents and other family members are employed in government offices where taking immediate decision is probably difficult.

Interestingly within middle social class, in order to purchase cars, in Alwar industrial city majority (45.1\%) took 'immediate decision" because more than one members are earning due to which they have surplus fund in their hands after family needs, whereas in Bharatpur their majority $(36.9 \%)$ counterparts took "one month time" as number of sampled respondents could be more in comparison to Alwar.

Further within lower social class, in order to purchase cars, in Alwar industrial town majority (29.4\%) took "less than a week," in Bharatpur their majority (40.6\%) counterparts took "more than one month time." The difference across lower social class within two industrial towns could be 
Study of Differences in Purchase Behaviour for High Involvement Consumer Durable Goods in Districts of Rajasthan U.C. Sharma, Mayank Sharma

due to the difference in their income, education, social and family responsibility and availability of fund to buy the cars. Findings of the study gives a clear indication to marketers of car companies and financial institutions to adopt different strategies and tactics to deal with the buyers belonging these two industrial cities.

In order to purchase computers, within upper social class, in both the cities majority (38.7\%) in Alwar and (53.3\%) in Bharatpur took "immediate decision." The existence of similarity in upper class in both the towns could be due to the fact computer is relatively less costly in comparison to car and it is useful for their children's exposure to computer and they want to provide them without giving much time to buy it.

However, there was a little difference within middle social class in both the cities. In Alwar majority (49\%) took "immediate decision," whereas majority $(32 \%)$ of their counterparts in Bharatpur took "less than a week" time, which could be due to gap in income, education, occupation and other differences prevailing which might be in both the towns particularly for people belonging to this social class.

In order to purchase refrigerators, within upper social class, both in Alwar and Bharatpur industrial city immediate decision were taken by majority of the respondents (58.1\%) in Alwar and $60 \%$ in Bharatpur city Counterparts. The existence of similarity in upper social class in both the industrial towns could be due to the fact that refrigerators has become a necessity and a variety of models with relatively lower price, better size, shape are available in the market. So people belonging to upper class having affordable income are taking immediate decision to buy refrigerator, without wasting time to buy this High Involvement Product (HIP). However, there was slight difference in middle class people in both the industrial city to purchase refrigerators. While in Alwar majority (52.9\%) took "immediate decision," in Bharatpur majority (38.8\%) of the respondents took "less than a week" time, which could be due to difference in their income, occupation and priority of people for refrigerator in comparison to other household goods. Interestingly to purchase refrigerators, within lower social class in Alwar industrial city majority (35.3\%) took "immediate decision," like upper class whereas in Bharatpur their majority $(37.5 \%)$ counterparts took "less than a week" time. The difference across lower social class within two industrial towns could be due to the difference in their income, social and family responsibility, and some time bank loan taken by the industrial buyers to buy this type of HIP.

For buying washing machines within upper social class, in Alwar and Bharatpur, majority (71\% and $60 \%$, respectively) of the respondents took "immediate decision" to think and buy washing machines. The similarity in upper class in both the industrial towns could be due to the fact that washing machine though a High Involvement Product (HIP) has become a necessity today and is available at a very affordable price, which does not require to spend more time to take decision for people of higher social class because of their income and other factors. However in case of middle class in Alwar majority (60.8\%) took "immediate decision," in Bharatpur majority (48.5\%) took "less than a week" time. This difference could be due to difference in income, occupation of 
spouse and other socio-cultural differences prevailing in both the towns. Similarly was the trend in case of lower social class to purchase washing machines in both the city due to similar reasons.

\section{MAJOR INFLUENCERS TO BUY HIPS}

Table 3 reveals that major influencers, to purchase cars. In upper social class, both in Alwar, and Bharatpur was "my own decision" (74.2\% and $46.7 \%$, respectively). The existence of similarity in upper class respondents of both the towns could be due to the fact that in upper social class the family besides affordable income to buy the car, it has become a necessity today. The cars are purchased through loan financed by the company or banks. So the individuals in this class may not be consulting others while buying their cars. Whereas within the majority of the middle social class respondents, major influencers in Alwar was (54.9\%) "my our decision" to purchase cars, and in case of their counterparts in Bharatpur it was "father" (35\%). This could be due to fact that in Alwar majority of the people are staying away from their parents, so in order to meet their day to day needs, and keeping in mind social and official status buy a car they are taking their own decision, whereas their counter parts in Bharatpur are consulting their "father" because majority of them could be staying with their parents, which supports findings of an earlier study by Verma (1982).

\begin{tabular}{|c|c|c|c|c|c|c|}
\hline \multirow[t]{2}{*}{ Products } & \multicolumn{3}{|c|}{ Alwar } & \multicolumn{3}{|c|}{ Bharatpur } \\
\hline & Upper Class & Middle Class & Lower Class & Upper Class & Middle Class & Lower Class \\
\hline Car & $\begin{array}{l}\text { My own } \\
\text { decision } \\
(74.2 \%)\end{array}$ & $\begin{array}{l}\text { My own } \\
\text { decision } \\
(54.9 \%)\end{array}$ & $\begin{array}{l}\text { Father } \\
(41.2 \%)\end{array}$ & $\begin{array}{l}\text { My own } \\
\text { decision } \\
(46.7 \%)\end{array}$ & Father $(35 \%)$ & $\begin{array}{l}\text { Father } \\
(37.5 \%)\end{array}$ \\
\hline Computer & $\begin{array}{l}\text { My own } \\
\text { decision } \\
(41.9 \%)\end{array}$ & $\begin{array}{c}\text { Children } \\
(23.5 \%)\end{array}$ & $\begin{array}{c}\text { Children } \\
(46.1 \%)\end{array}$ & $\begin{array}{l}\text { My own } \\
\text { decision } \\
(33.3 \%)\end{array}$ & $\begin{array}{l}\text { My own } \\
\text { decision } \\
(28.2 \%)\end{array}$ & $\begin{array}{l}\text { Children and } \\
\text { My own } \\
\text { Decision } \\
(62.6 \%)\end{array}$ \\
\hline Refrigerator & Wife $(54.8 \%)$ & Wife $(70.6 \%)$ & Wife $(47.1 \%)$ & Wife $(53.3 \%)$ & Wife (32\%) & $\begin{array}{l}\text { My own } \\
\text { decision } \\
(25 \%)\end{array}$ \\
\hline $\begin{array}{l}\text { Washing } \\
\text { Machine }\end{array}$ & Wife $(71 \%)$ & Wife $(80.4 \%)$ & Wife $(41.2 \%)$ & Wife $(46.7 \%)$ & Wife (33\%) & $\begin{array}{l}\text { Mother and } \\
\text { Wife }(50 \%)\end{array}$ \\
\hline
\end{tabular}

Source: Primary data

Interestingly, major influencers among the majority of lower social class respondents, both in Alwar and Bharatpur was "father" $(41.2 \%$ and $37.5 \%$, respectively). The similarity could be because of the fact that consumers belonging to this social class could be taking financial support from their father or it could be the fact that a traditional culture still prevails in lower social class where father plays an important role in purchase decision.

Major influencers, to purchase computers in upper social class, both in Alwar and Bharatpur was "my own decision" $(41.9 \%$ and $33.3 \%$, respectively). The existence of similarity in upper class in both the towns could be due to the need for computers are felt by 
everyone, so natural to take a decision on own, which supports the findings of an earlier study by Verma (1982).

Whereas within the majority of the middle social class respondents, major influencers in Alwar were $(46.1 \%)$ "children" to purchase computers, whereas incase of their counterparts in Bharatpur it was "my own decision" $(28.2 \%)$, could be due to fact that in Alwar majority of the people are staying away from their parents, so in order to meet the computer needs of their children, they are taking their own decision, whereas their counter parts in Bharatpur are consulting their "father" because majority of them could be staying with their parents and they could be old and retired and sometimes to make them feel happy and might be consulting them to buy this product. Interestingly, the majority of lower social class respondents, major influencers both in Bharatpur and Alwar were "children." The similarity across lower social class within the two industrial city could be because these days children play important role due to their exposure to new technology and knowledge gained out of their exposure, while purchasing high involvement product such as computers. Which supports the findings of earlier study by Ambani (1978), Das (1987), Foxman and Tansuhaj (1989), Lackman and Lanasa (1993), Verma and Kapoor (1993) and Sujeet(2000).

Interestingly, in upper and middle class respondents major influencers to purchase refrigerators, both in Alwar and Bharatpur were "wife" The similarity in upper class and middle class of both the city could be due to the fact that ladies in the home are users of the refrigerators and exposed to advertisements, TV, news papers, and magazines. So they play dominant role in purchase of refrigerators, which supports findings of earlier study by Gupta (1990), Verma and Kapoor (2003).

In order to purchase washing machines in upper, middle and lower social class, in Alwar, majority $(71 \%, 80.4 \%$ and $41.2 \%$, respectively) of the respondents are influenced by "wife." The similarity could be due to the fact that ladies in the home are users of the washing machines, so they play an important role in purchase of washing machines. The findings of the study support findings of an earlier study by Venkateshwarlu and Rao (2000), and Verma and Kapoor (2003).

In Bharatpur, both in upper and middle social class, major influencers incase of majority of the respondents (46.7\% and 33\%, respectively) was "wife" to purchase washing machines, whereas major influencers incase of majority of the lower social class respondents was "wife" as well as "mother" (50\%). The slight difference across lower social class within two industrial city could be because wife plays important role in nuclear families in Alwar, whereas in Bharatpur, joint family system prevails where traditionally mother also plays her role, which support findings of earlier study by Gupta (1990).

\section{CONCLUSIONS AND SUGgestions}

To conclude, no doubt there exist social class differences in purchase of HIPS, but the difference exist across cities which needs to be taken care by the marketers in order to market their products and services. In order to increase the sale of high involvement products (HIPS) the marketers need to use appropriate marketing mix with respect to product, price, 
promotion, distribution, people etc., so that it fits with their needs and desires and motivate them to take their purchase decisions. Since cognitive dissonance arises more in HIPS, they need to evolve appropriate marketing strategy so that words of mouth publicity for this type of product will increase the demand for the products. The study of social factors influence in consumer buying behavior, develops deep insight in a marketer to understand and analyse how social class as a strong determinant can be used to segment the consumers and develop tactics to motivate and facilitate them to buy different consumer durable with different mode of payment. In fact the knowledge of social class enables marketers to take appropriate decision relating which news papers, magazines, televisions, outdoors ads are to be used for different social classes for purchase of their durable goods. The knowledge of social class give idea to banks and financial institutions to evolve appropriate strategy to encourage consumers to take loans for buying HIPS.

\section{REFERENCES}

[1]. Ambani, G. (1978). Social Class and Buyer Behaviour-Study on Selected durables (Television), MBA Dissertation, Kurukshetra University, Kurukshetra.

[2]. Brown, Juanita J., Gray, James I. and Korgaonkar, Pradeep K. (1992). “The Effect of Social Class and Perceived Risk on Consumer Preferences for Electronic Shopping." International Journal of Management, Vol. 9, No. 1, March, P.P. 97-105.

[3]. Coleman, Richard, P. (1983). Continuing Significance of Social Class to Marketing. Journal of Consumer Research. PP. 265-280, Dec.

[4]. Das, R. P. (1987). Consumer Behaviour in Television -A Case Study, Research Journal (Arts and Humanities), Kurukshetra University, Kurukshetra (Vol. XX-XXI), PP. 16-21.

[5]. Dogra, B.S. and Chauhan, J. (1979). Consumer Behaviour in Television - A Case Study of Simla Market, Indian Journal of Marketing, 7(3), PP.21-31.

[6]. Ghosh, A., Mukharjee, A. and Badrinath, V.V. P. (1997). Zero in on the Indian Consumer: Strategic Marketing, The Economic Times. March.

[7]. John, S. (2002). Times News Network, The Sunday Times of India. February, 3.

[8]. Kahl, Joseph A. (1957). The American Class Structure, New York: Rinehart.

[9]. Kotler, Phillip. (2003). Marketing Management. 11 th Ed., Pearson Education( Singapore) Pte. Ltd.

[10]. Kuppuswamy, B. (1959). "A Scale to Measure Socio-Economic Status." Indian Journal of Psychology, 34, 1, P.P. 1-10.

[11]. Llyod, Warner. (1949). Democracy in Jonesvilla. New York: Harper and Brothers.

[12]. Lynne, R. Kahle, (1986). The Nine Nations of North America and The value basis of Geographic Segmentation. The Journal of Marketing, 50, PP.37-47, April.

[13]. Martineau, Pierre. (1958). Social Classes and Spending Behaviour. Journal of Marketing, vol. 23, PP. 121, Oct. 
Study of Differences in Purchase Behaviour for High Involvement Consumer Durable Goods in Districts of Rajasthan U.C. Sharma, Mayank Sharma

[14]. Nair, R. Suja, (2001). Consumer Behaviour in Indian Perspective. $1^{\text {stEdition, Himalaya }}$ Publishing House, PP. 219-220.

[15]. Plummer, T. Joseph. (1989). Changing Values. Futurist, PP.8-13, January / February.

[16]. Rich, S.U. and Jain, S.C. (1968). Social Class and Life cycle as predictors of shopping Behaviour. Journal of Marketing Research. PP. 41-49, February, 5.

[17]. Roger, D. Blackwell, Paul, W. Miniard, Engel, F. James, (2001). Consumer Behavior. 9 ${ }^{\text {th }}$ Ed., Thompson Asia Pvt. Ltd., Singapore.PP.314, 323-329.

[18]. Shiffman, Leon G., Kanuk, Leslie L., (1996). Consumer Behavior $5^{\text {th }}$ Ed., Prentice Hall of India Ltd., New Delhi., PP.9-10.

[19]. Takada, H and Jain, D. (1991). Cross National Analysis of Consumer Durable Goods in Pacific Rim Countries. Journal of Marketing, 55, PP.48-53.

[20]. Vidich, Arthur and Bensman, Joseph (1960). Small Towns in Mass Society. New York: Anchor Books, Inc.,

[21]. Walter, C. G., Consumer Behaviour: The Theory and Practice. $3^{\text {rd }}$ Ed., South Illinois University, Richard D. Irwin, Inc., Homewood Illinois-60430.

[22]. Zikmund, William G. and Amico, Michael D'. (2001). Marketing Creating and Keeping Customers in an e-Commerce World. $7^{\text {th }}$ Ed., South Western College Publishing, PP.154160. 